\title{
Variability in muscle growth characteristics during the spawning season in a natural population of Atlantic herring Clupea harengus
}

\author{
Genevieve K. Temple ${ }^{1, *}$, Clive J. Fox ${ }^{2}$, Ron Stewart ${ }^{1}$, Ian A. Johnston ${ }^{1}$ \\ ${ }^{1}$ Gatty Marine Laboratory, Division of Environmental and Evolutionary Biology, School of Biology, \\ University of St. Andrews, St. Andrews KY16 8LB, Fife, United Kingdom \\ ${ }^{2}$ The Centre for Environment, Fisheries and Aquaculture Science (CEFAS), Pakefield Road, Lowestoft NR33 0HT, Suffolk, \\ United Kingdom
}

\begin{abstract}
Muscle growth characteristics were investigated in a herring Clupea harengus L. population in the Blackwater estuary, Essex, England, between May and July 1998. Larval thermal histories were reconstructed using internally logging temperature recorders deployed within the estuary over the spawning season. The hatch dates of larvae were estimated using otolith microincrement analysis. Larvae were split into 3 groups; those developing from eggs laid early in the season when temperatures were low $\left(6.4\right.$ to $\left.9.8^{\circ} \mathrm{C}\right)$, those developing mid-season $\left(8.3\right.$ to $\left.12.5^{\circ} \mathrm{C}\right)$, and those developing late $\left(10.9\right.$ to $\left.15.6^{\circ} \mathrm{C}\right)$. The number and size distribution of red and white myotomal muscle fibres varied between larvae from early- and mid-spawners in relation to estimated age. At approximately $60 \mathrm{~d}$, the cross-sectional area of white muscle in mid-season larvae was $145 \%$ greater than in earlyseason larvae of an equivalent age because of $60 \%$ more muscle fibres and a $22 \%$ greater mean fibre diameter. The number and average diameter of red muscle fibres were proportional to body length, with no differences between the groups of larvae. However, for a given length, the average diameter of the white muscle fibres was significantly greater in mid- than early-season larvae. Muscle cellularity therefore varied for cohorts of larvae hatching at different times during the spawning season.
\end{abstract}

KEY WORDS: Clupea harengus L. Herring larvae $\cdot$ Muscle cellularity $\cdot$ White muscle $\cdot$ Red muscle Fibre hypertrophy $\cdot$ Fibre recruitment

Resale or republication not permitted without written consent of the publisher

\section{INTRODUCTION}

Around the British Isles populations of Atlantic herring Clupea harengus L. spawn at different times of the year. The larvae spend 2 to 6 mo in the plankton, depending on the spawning period (Doyle 1977). During the larval stage, the transparent larvae complete organogenesis, develop capillary circulation, and gradually develop fins and the juvenile body form (Batty 1984, Johnston 1993). Metamorphosis from the larval to juvenile stage begins at around $28 \mathrm{~mm}$ total length (L), is complete by 35 to $42 \mathrm{~mm} \mathrm{~L}$, and involves the acquisition of functional gill filaments, pigmentation of the blood and silvering of the body (de Silva 1974).

*E-mail: gkt@st-and.ac.uk
The trunk musculature of fish may constitute 60 to $70 \%$ of the body mass, and in adults is composed primarily of red and white muscle fibres which correspond to slow and fast-twitch fibres, respectively (Altringham \& Johnston 1988). The red muscle powers continuous swimming at slow to intermediate speeds, whilst the white muscle, which constitutes the bulk of the muscle mass, is recruited at high speeds as used during prey capture and escape manoeuvres (Johnston et al. 1977, Bone et al. 1978, Rome et al. 1988). Herring larvae hatch with a superficial layer of red muscle fibres surrounding an inner core of white muscle fibres (Batty 1984). Both embryonic fibre types are distinct from the adult types (Crockford \& Johnston 1993), but are gradually replaced by them between around 18 and $28 \mathrm{~mm} \mathrm{~L}$ (Johnston \& Horne 1994, Johnston et al. 
1998). Johnston et al. (1998) have outlined 3 distinct phases of white muscle growth in herring larvae. The first period, up to $12 \mathrm{~mm} \mathrm{~L}$, involves hypertrophy of the embryonic muscle fibres. The second phase, from 15.6 to $18.4 \mathrm{~mm} \mathrm{~L}$, involves the production of new fibres from germinal zones at the dorsal and ventral margins of the myotome. The third phase involves the activation of satellite cells scattered throughout the myotome. Satellite cells are mononuclear cells that, once activated, proliferate a limited number of times to provide a source of nuclei for hypertrophy and new fibre production (Koumans et al. 1991, Johnston et al. 1995). The number of white muscle fibres per myotomal cross-section, taken $0.4 \mathrm{~L}$ from the snout, increases from around 300 at hatching to 12000 at the end of metamorphosis (Johnston et al. 1998). In sexually mature adults, numbers reach 30000 to 60000 (GreerWalker et al. 1972).

During ontogeny, larvae experience changing temperature regimes. Around the British Isles, a number of herring stocks spawn in the spring or autumn, such that embryos and larvae develop during periods of increasing or decreasing water temperatures, respectively. Laboratory experiments conducted on the spring-spawning Clyde herring stock have shown that developmental temperature affects the number and diameter of the muscle fibres in herring embryos (Vieira \& Johnston 1992, Johnston 1993). Indeed, temperature affects the relative timing and expression patterns of many components of the myogenic programme. The expression of adult myofibrillar protein isoforms, red muscle multiple innervation, and the development of the median fins, were all found to be delayed with respect to body length at lower developmental temperatures (Johnston et al. 1997, 1998). There is evidence that embryonic temperature alters muscle growth characteristics post-hatching by altering the number of muscle satellite cells. Embryos of spring-spawning Clyde herring reared at $8^{\circ} \mathrm{C}$ had a significantly higher density of mononuclear cells in the white muscle than embryos reared at $5^{\circ} \mathrm{C}$ (Johnston 1993). In subsequent experiments, larvae were reared at 5 and $8^{\circ} \mathrm{C}$ until first feeding and then transferred to ambient temperature. After $80 \mathrm{~d}$, fish initially reared at $8^{\circ} \mathrm{C}$ had recruited significantly more muscle fibres of larger diameter than fish initially reared at $5^{\circ} \mathrm{C}$, correlating with the higher density of muscle satellite cells (Johnston et al. 1998).

Whilst muscle growth characteristics have been investigated in laboratory-reared Atlantic herring Clupea harengus L. (Vieira \& Johnston 1992, Johnston 1993, Johnston et al. 1995, 1997, 1998), the muscle development of field-spawned larvae has not previously been studied. Larval mortality in natural populations of herring is high and can reach $20 \% \mathrm{~d}^{-1}$ (Heath \&
MacLachlan 1987). Survival through the larval stages and ultimately recruitment to the adult population is believed to be linked to fast growth rates which reduce the risk of predatory mortality (Cushing 1990).

The aim of this study was to examine whether muscle growth characteristics varied over a spawning season in a natural population of herring. A field study was conducted on a herring population in the Blackwater estuary, off the Essex coast, England. This stock was chosen because larvae hatch in batches during the spring at a time of increasing water temperatures, the main spawning ground on the Eagle Bank is restricted, and the larvae stay in the system, developing for up to 2 mo (Henderson \& Cartwright 1980, Henderson et al. 1984).

\section{MATERIALS AND METHODS}

Temperature recordings. In order to record temperatures in the Blackwater estuary over the herring $\mathrm{Clu}$ pea harengus L. spawning season, divers suspended temperature loggers (Vemco Minilog TR, Hydrosphere UK Ltd, Farnham, Surrey) underwater at a depth of around $2 \mathrm{~m}$ from buoys at North Eagle, Bench Head and Thirslet (Fig. 1); 2 loggers were deployed at each location. The loggers were set to record the temperature at $30 \mathrm{~min}$ intervals, and had a resolution of $\pm 0.1^{\circ} \mathrm{C}$ with an accuracy of $\pm 0.2^{\circ} \mathrm{C}$. Loggers were placed on the buoys on 18 February 1998 and recovered on 30 June 1998.

Larval sampling. Plankton sampling was carried out on 11 May, 18 June and 24 July 1998 using a bongo net with a $275 \mu \mathrm{m}$ mesh cod-end. The net was towed slowly at 1 to 2 knots for $5 \mathrm{~min}$ close to the surface. Upon recovery, the contents of the cod-end were washed into a plastic tray and sorted for clupeoid larvae. Herring larvae were found in the area from Bradwell out to the Bench Head buoy (Fig. 1).

Larvae were decapitated using a scalpel. The heads were preserved in calcium carbonate-buffered alcohol $(70 \% \mathrm{v} / \mathrm{v})$ and the bodies were fixed in Bouin's fixative for $24 \mathrm{~h}$ before transferring to $80 \%$ (v/v) alcohol. Myotome counts were performed on all bodies to confirm them as herring. Head and body lengths were measured separately using an interactive image-analysis system (PISCES, Perceptive Instruments, Haverhill, Suffolk, UK). Lengths were corrected for shrinkage using the formulae given in Fox (1996), and the standard live lengths of the larvae estimated by summation.

Otolith microincrement analysis. The heads of 52 larvae were processed for otolith microincrement analysis at the CEFAS laboratory, Lowestoft. The sagittal otoliths of each specimen were dissected using fine needles, and the otoliths were mounted in thermoplastic resin (Crystallbond, Components Products Ltd, 


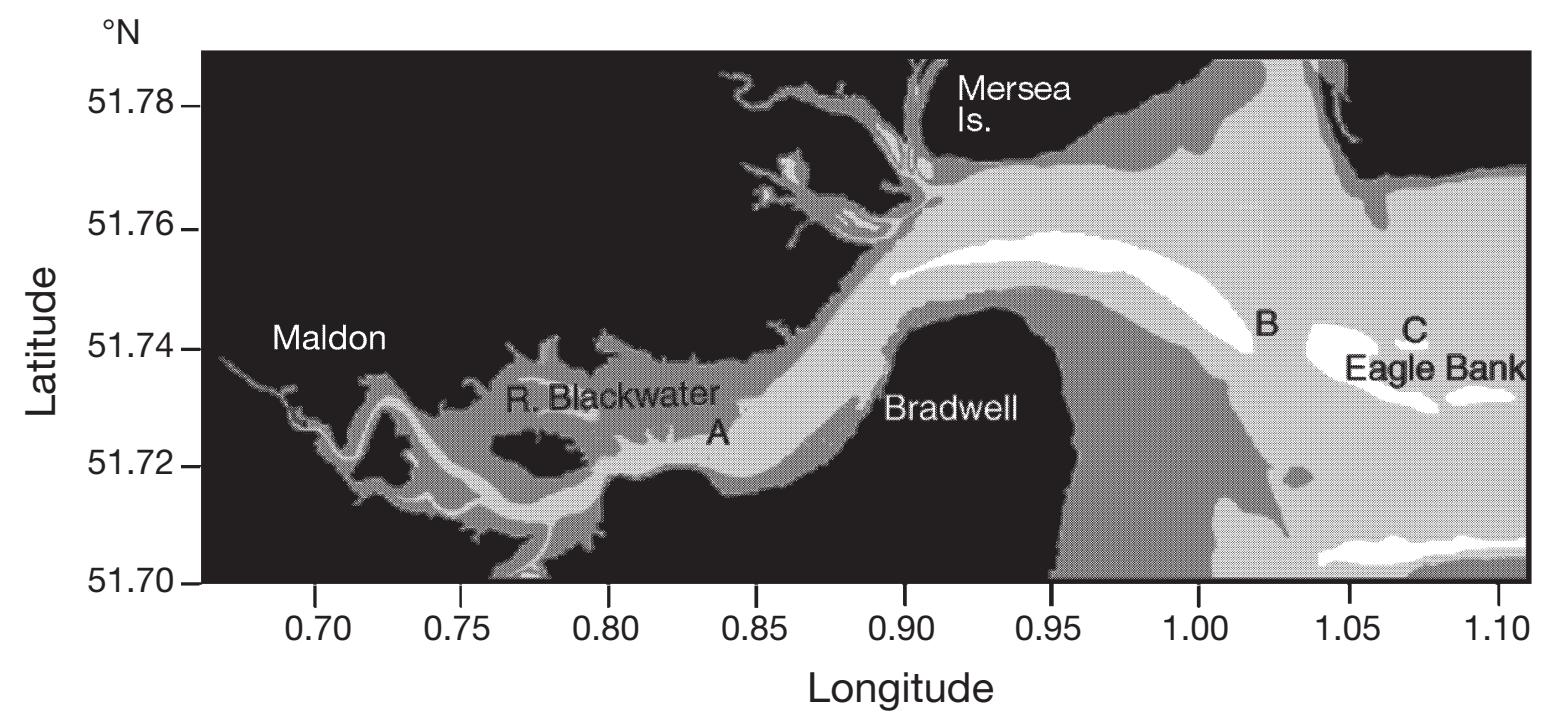

Fig. 1. Map of Blackwater Estuary. A: Thirslet buoy; B: Bench Head buoy; C: North Eagle buoy; mid-grey shading: foreshore; light grey shading: $<10 \mathrm{~m}$ charted depth; white areas: $>10 \mathrm{~m}$ charted depth

Sidcup, Kent, UK). The otoliths were ground to the nuclear core using graded aluminium oxide paper (Testbourne Ltd, Basingstoke, UK) and polished using an aluminium oxide block (Evans Lapidary, Dartford, Kent, UK). Gross measurements of the otoliths (length, width, perimeter and circularity) were made under a $\times 40$ objective using the PISCES image-analysis system described above. The otoliths were then viewed under a $\times 100$ oil-immersion objective, and counts were made of the increments. The otoliths were read twice in a random order by the same investigator. The counts were then compiled and those otoliths for which ring counts differed by $>10 \%$ either side of the mean were re-examined in an attempt to reconcile the counts. The mean count was then calculated for each specimen. Usually this was based on 4 counts for each larva (2 replicate counts for each otolith). However, 5 otoliths were destroyed due to overgrinding.

Muscle fibre analysis. Histological analysis was carried out at the Gatty Marine Laboratory, St. Andrews. The Bouin's fixed bodies were processed for wax histology. Serial $7 \mu \mathrm{m}$ sections were cut transversely to the longitudinal body axis $0.4 \mathrm{~L}$ from the tip of the snout and mounted on poly-L-lysine coated slides (Fig. 2). Sections were de-waxed with xylene, rehydrated and stained with haematoxylin-eosin. The cross-sectional area (CSA) and diameter of each fibre within one-half of a section was determined using image-analysis (Kontron Elektronik, Basel). Larvae were assumed to be bilaterally symmetrical, and therefore the total number of muscle fibres and CSA of muscle were twice that measured.

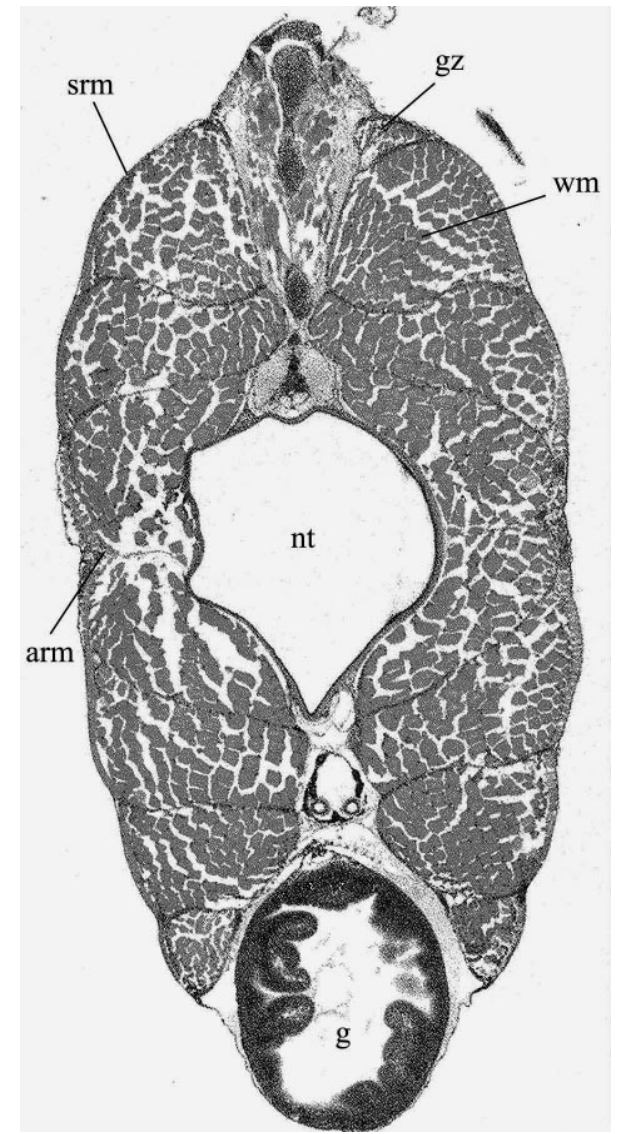

Fig. 2. Clupea harengus. Haematoxylin-eosin stained transverse section of myotomal muscle in early-season herring larva, $19.6 \mathrm{~mm}$ length, with estimated age of $55 \mathrm{~d}$. gz: germinal zone; srm: superficial red muscle; wm: white muscle; arm: adult red muscle; nt: notochord; g: gut 
Statistical analysis. Since the 3 sampling days appeared to sample consecutive groups of larvae, each of comparable ages and lengths, the larvae were kept as 3 individual groups. Linear regressions $(y=b x+a$, where $x=$ live length or age) were calculated using least-squares regression analysis. The significance of all regression lines was assessed using the ANOVA F-statistic. ANCOVA was used to test for differences in regression lines. Slopes (exponent $b$ ) were compared using the first stage of ANCOVA. Where no differences were found, the second stage of ANCOVA was used to test for differences in regression elevations (intercept a). Where $>2$ slopes were compared, Tukey multiple-comparison tests were used to determine between which groups differences lay. All statistical tests were carried out following Zar (1996) and were considered significant at a $95 \%$ confidence level.

Non-parametric statistical techniques were used to fit smoothed probability density-functions to the measured muscle fibre diameters of earlyand mid-season larvae of $23.7 \pm$ $0.7 \mathrm{~mm} \mathrm{~L}$ (mean $\pm \mathrm{SD}$ ), as described by Johnston et al. (1999). The average smooth probability densityfunctions were estimated using the pooled diameters for each group and the mean optimal smoothing parameter (Bowman \& Azzalini 1997). The smoothing parameter was 0.169 for early-season larvae and 0.179 for mid-season larvae. In order to restrict diameters to positive values, density functions were estimated for the natural logarithm of diameter and then transformed back to the original scale. Six larvae were selected from each group and then 900 muscle fibres were selected at random per larva. To maintain consistency when comparing tail percentiles, the maximal diameter within groups was fixed at $110 \%$ of the maximum diameter sampled. The 5th, 10th, 50th, 95th and 99th percentiles of muscle fibre diameter were calculated from the distributions. A Wilcoxon rank-sum 2-sample non-parametric test was used to test the hypothesis that the median value of the specified percentile was equivalent between groups.

\section{RESULTS}

\section{Temperature recordings}

The loggers recorded temperature from the upper $2 \mathrm{~m}$ of water. Although Clupea harengus eggs are benthic, the estuary is shallow (often $<10 \mathrm{~m}$ ) and extremely tidally energetic, ensuring a vertically mixed water column (Fox unpubl. data). Temperatures at North Eagle and Bench Head were similar, whilst those at Thirslet were generally 1 to $2^{\circ} \mathrm{C}$ higher (Fig. 3a). Since larvae were only found as far up the
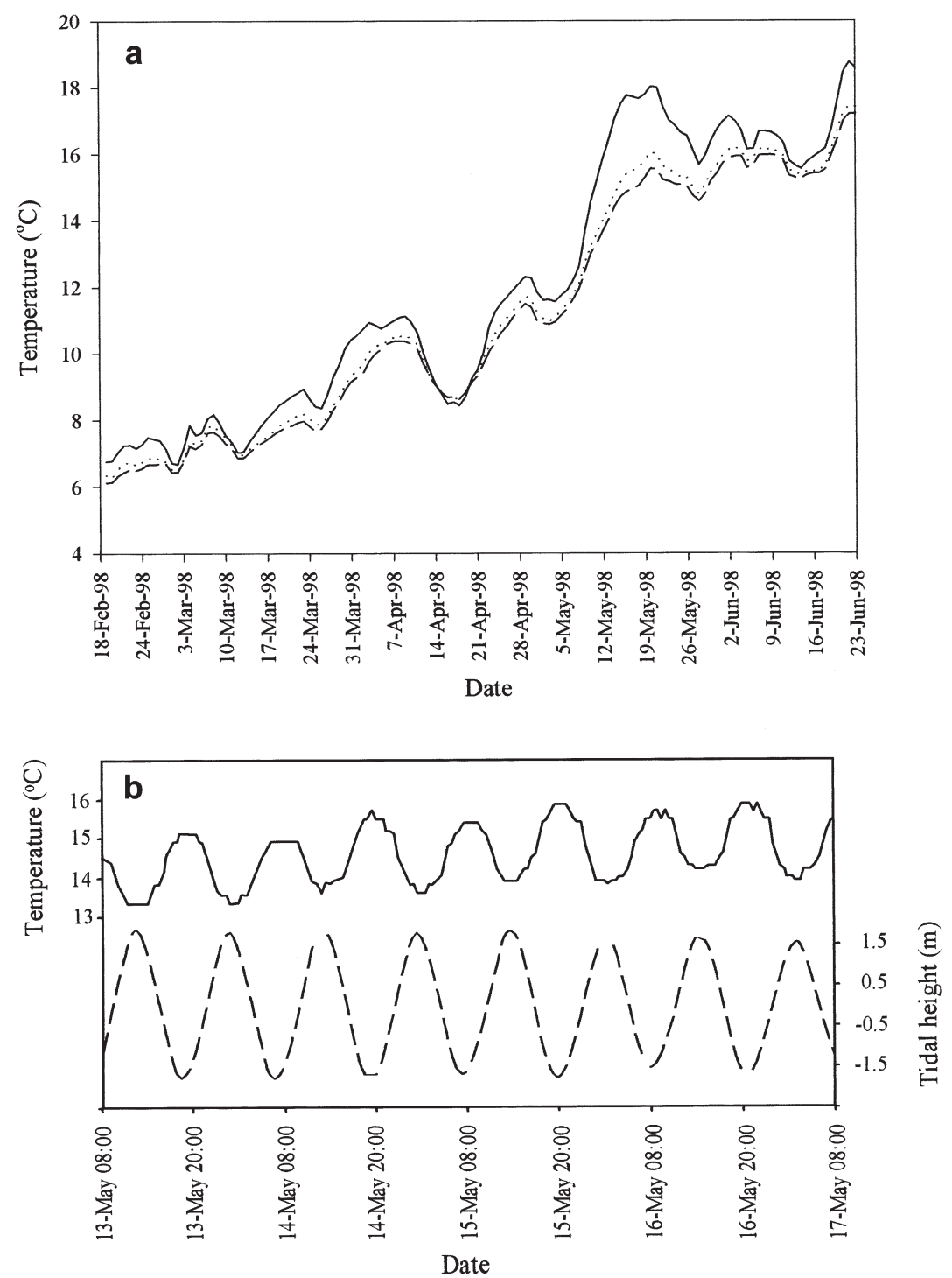

Fig. 3. Clupea harengus. (a) Mean daily sub-surface water (2 m depth) temperature at Thirslet (continuous line), Bench Head (dotted line) and North Eagle (dashed line) during spring 1998. (b) Comparison of predicted tidal height (dashed line) against recorded surface water temperature (continuous line) at North Eagle over a 4 d period during May 1998 (abcissa shows the time of day in hours) 
river as Bradwell, only temperature data for North Eagle are discussed. Temperatures increased gradually from $6^{\circ} \mathrm{C}$ on 19 February to $12^{\circ} \mathrm{C}$ by 8 May, and then more rapidly to $15^{\circ} \mathrm{C}$ by 18 May (Fig. 3a). However, tidally induced temperature cycling of about $1.5^{\circ} \mathrm{C}$ was a prominent feature (Fig. 3b). Warmer water was associated with the ebb, and cooler water with the flood.

\section{Otolith microincrement analysis}

The first otolith microincrement is generally laid down 20 d post-hatch in Blackwater herring (Fox unpubl. data). Hatch dates of the larvae were calculated assuming that increments were deposited daily after this period. Suboptimal conditions, such as extreme temperature and poor feeding, have been found to lead to increment formation occurring at rates of $<1 \mathrm{~d}^{-1}$ (Geffen 1983, Hovenkamp \& Witte 1991). In such slow-growing larvae, it is possible that daily growth increments are formed but are too fine to resolve with light microscopy (Campana et al. 1987). Gallego et al. (1996) found no evidence for sub-optimal growth conditions in a natural population of herring larvae off the north coast of Scotland. However, there is some unavoidable error involved with ageing larvae in this way, and caution should be exercised in the interpretation of the results involving age estimates.

Successive sampling on 11 May, 18 June and 24 July 1998 appeared to sample consecutive cohorts. Larvae caught on 11 May were estimated to have hatched between 1 March and 3 April 1998. Larvae sampled on 18 June were estimated to have hatched between 9 April and 9 May 1998, whilst those caught on 24 July were estimated to have hatched between 12 May and 5 June 1998. The 3 cohorts experienced mean temperatures on hatching of $7.5 \pm 0.9$ (mean $\pm \mathrm{SD}), 9.8 \pm$ 1.1 and $14.9 \pm 0.6^{\circ} \mathrm{C}$, and are referred to as early-, mid- and late-season larvae, respectively. The groups showed different growth characteristics (Fig. 4). Earlyseason larvae had an estimated growth rate of $0.23 \mathrm{~mm}$ $\mathrm{d}^{-1}$, mid-season larvae $0.34 \mathrm{~mm} \mathrm{~d}^{-1}$, and late-season larvae $0.09 \mathrm{~mm} \mathrm{~d}^{-1}$, although the latter group did not produce a significant regression and, because of the small numbers involved ( $\mathrm{n}=7$ ), was omitted from the major analysis. Although the growth patterns were not significantly different between the mid- and early-season larvae (common slope exponent $b$ of $0.27 \mathrm{~mm} \mathrm{~d}^{-1}$ ), the value of the intercept a was significantly higher in the mid-season larvae $\left(F_{[1,37]}=51.54, \mathrm{p}<0.001\right.$; ANCOVA). Despite the error involved with ageing the larvae, we believe that the rank order of hatch dates is correct, based on the reasonable growth rates of the 2 main groups of larvae.

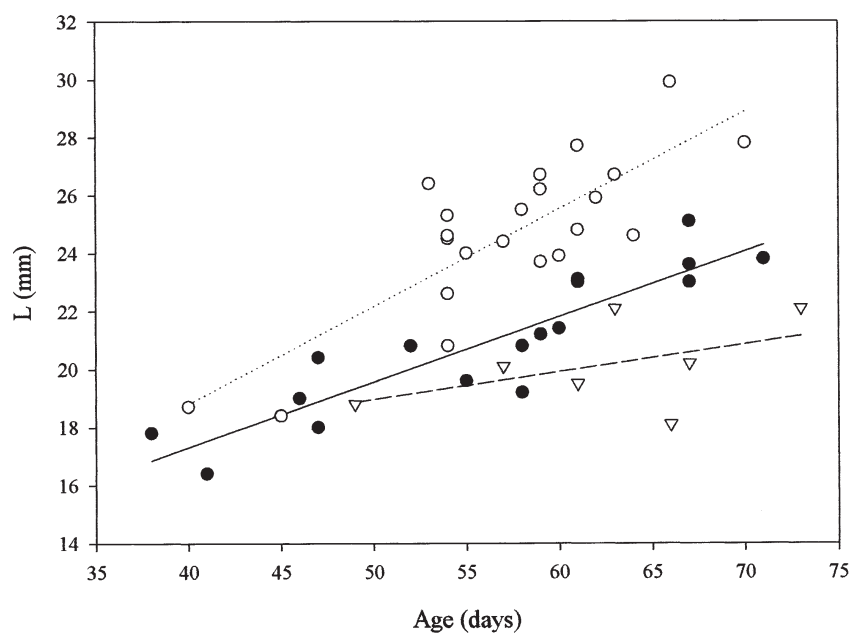

Fig. 4. Clupea harengus. Growth patterns for early (•, continuous line)-, mid ( $O$, dotted line)- and late $(\nabla$, dashed line)-season larvae using age derived from otolith microincrement analysis. L: length

\section{Muscle growth characteristics}

All parameters measured (CSA, fibre number, fibre diameter, nuclei number) in the early- and mid-season larvae produced significant regressions with age and length, as tested using the $F$-statistic. Compared to mid-season larvae, early-season larvae between around 50 and $70 \mathrm{~d}$ old were thinner, due to having fewer muscle fibres that were of a smaller diameter (Fig. 5). The rates of growth of both red and white fibre CSA were significantly higher in the mid- than the early-season larvae (red fibres, $F_{[1,36]}=8.41, \mathrm{p}=$ 0.006; white fibres, $F_{[1,36]}=8.86, \mathrm{p}=0.005$; ANCOVA) (Tables $1 \& 2$, Fig. 5a). White fibre recruitment was 37 and 81 fibres $\mathrm{d}^{-1}$ for the early- and mid-season larvae, respectively $\left(F_{[1,36]}=9.97, \mathrm{p}=0.003\right.$; ANCOVA $)$ (Tables 1 \& 2, Fig. 5b). Red muscle fibre recruitment was 4 and 6 fibres $\mathrm{d}^{-1}$ for the early- and mid-season larvae, respectively (Table 1). These latter rates were not significantly different, but mid-season larvae had significantly more fibres than early-season larvae of the same age (intercept $a, F_{[1,37]}=30.1, \mathrm{p}<0.0001$; ANCOVA) (Table 2). As development proceeded, muscle fibre diameters increased via hypertrophic growth. Mean fibre diameters were less in the early- than midseason larvae (red muscle, $F_{[1,37]}=27.27, \mathrm{p}<0.001$; white muscle, $F_{[1,37]}=81.98, \mathrm{p}<0.001$; ANCOVA) (Tables 1 \& 2, Fig. 5c). The total number of muscle nuclei increased with age in both groups of larvae, but was significantly higher in the mid- than the earlyseason larvae $\left(F_{[1,37]}=5.44, \mathrm{p}=0.025\right.$; ANCOVA $)$ (Tables $1 \&$ 2, Fig. 5d).

Red muscle CSA, fibre number and mean fibre diameter, increased with increasing body length (Table 1), 

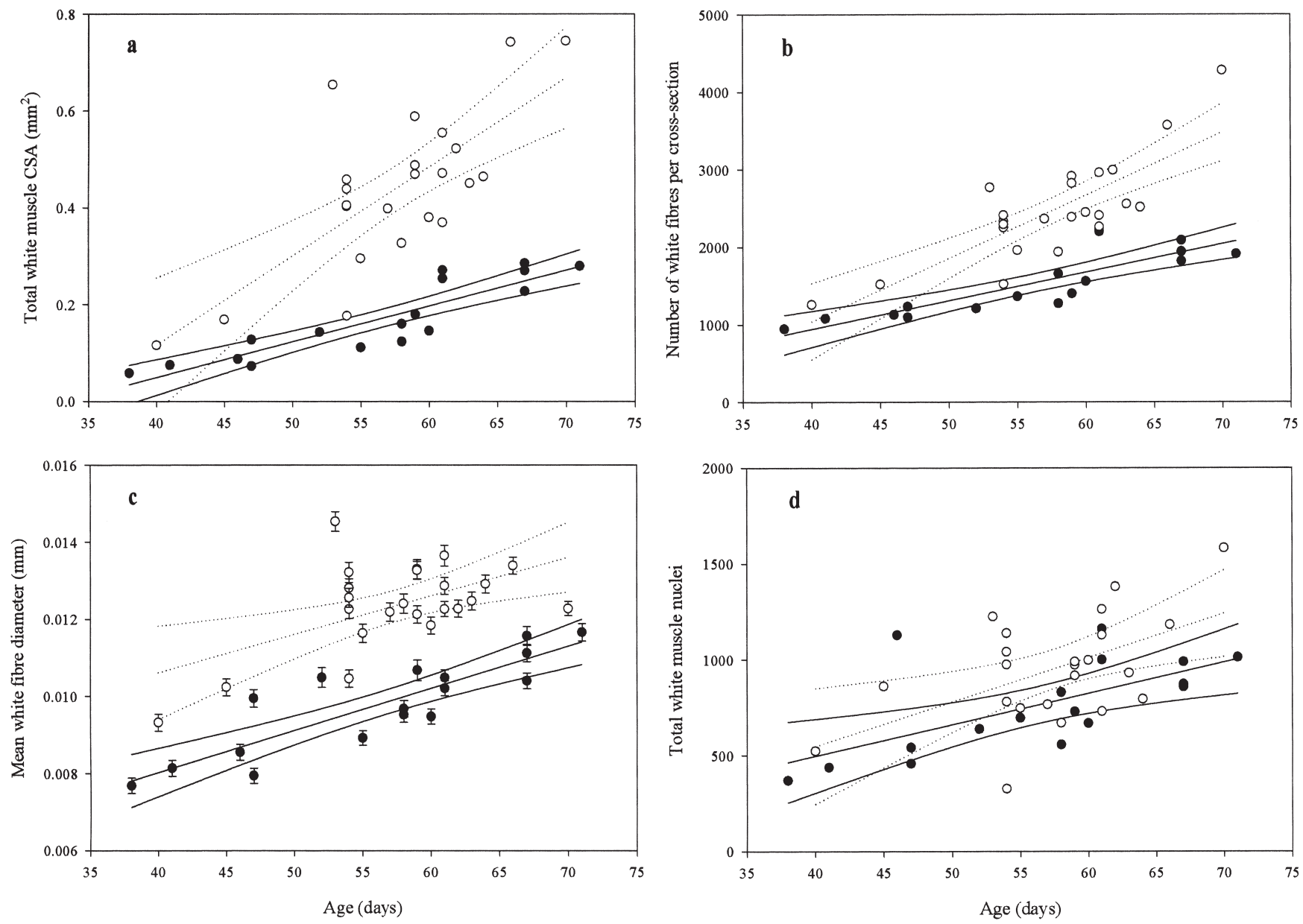

Fig. 5. Clupea harengus. Relationship between estimated age and (a) total white muscle cross-sectional area (CSA), (b) total number of white muscle fibres, (c) mean $( \pm \mathrm{SE})$ diameter of white fibres, and (d) total number of white muscle nuclei, per transversesection of myotomal muscle in early (•, continuous lines)- and mid ( $\mathrm{O}$, dotted lines)-season larvae. Least-squares regression lines are shown with $95 \%$ confidence intervals

Table 1. Clupea harengus. Regression of larval length on age; of red and white muscle cross-sectional area (CSA), fibre number and fibre diameter on age and length; and of total white muscle nuclei on age and length

\begin{tabular}{|c|c|c|c|c|c|c|c|}
\hline \multirow[t]{2}{*}{ Variable } & \multirow[t]{2}{*}{ Factor } & \multicolumn{3}{|c|}{ Early-season larvae } & \multicolumn{3}{|c|}{ Mid-season larvae } \\
\hline & & $a$ & $b$ & $\mathrm{r}^{2}$ & a & $b$ & $r^{2}$ \\
\hline Length & Age & 8.29 & 0.23 & 0.81 & 5.35 & 0.34 & 0.66 \\
\hline Red CSA & Age & -0.019 & 0.0006 & 0.80 & -0.046 & 0.0013 & 0.61 \\
\hline Red fibre number & Age & 45.56 & 3.59 & 0.55 & -47.38 & 6.46 & 0.49 \\
\hline Mean red fibre diameter & Age & 0.0010 & 0.0001 & 0.76 & 0.0009 & 0.0001 & 0.53 \\
\hline White CSA & Age & -0.247 & 0.007 & 0.80 & -0.619 & 0.018 & 0.55 \\
\hline White fibre number & Age & -529.39 & 36.77 & 0.71 & -2216.52 & 81.42 & 0.65 \\
\hline Mean white fibre diameter & Age & 0.0037 & 0.0001 & 0.75 & 0.0066 & 0.0001 & 0.32 \\
\hline White fibre nuclei & Age & -156 & 16 & 0.42 & -376 & 23 & 0.28 \\
\hline Red CSA & Length & -0.038 & 0.003 & 0.86 & -0.047 & 0.003 & 0.57 \\
\hline Red fibre number & Length & -46.31 & 14.00 & 0.53 & -95.76 & 17.01 & 0.59 \\
\hline Mean red fibre diameter & Length & -0.0027 & 0.0005 & 0.80 & 0.0012 & 0.0003 & 0.46 \\
\hline White CSA & Length & -0.49 & 0.03 & 0.90 & -0.79 & 0.05 & 0.69 \\
\hline White fibre number & Length & -1749.61 & 156.82 & 0.81 & -2368.0 & 195.81 & 0.65 \\
\hline Mean white fibre diameter & Length & 0.0005 & 0.0004 & 0.78 & 0.005 & 0.0003 & 0.53 \\
\hline White fibre nuclei & Length & -737 & 72 & 0.50 & -629 & 64 & 0.38 \\
\hline
\end{tabular}


Table 2. Clupea harengus. Regression analysis of red and white muscle CSA, fibre number, fibre diameter and white muscle nuclei in early- and mid-season larval groups. ns: not significant

\begin{tabular}{|c|c|c|c|c|c|}
\hline \multirow[t]{2}{*}{ Variable } & \multirow[t]{2}{*}{ Factor } & \multicolumn{2}{|c|}{ ANCOVA Stage 1} & \multicolumn{2}{|c|}{ ANCOVA Stage 2} \\
\hline & & $F$-value & $\mathrm{p}$ & $F$-value & $\mathrm{p}$ \\
\hline Length & Age & & & 51.55 & $<0.0001$ \\
\hline Red CSA & Age & 8.41 & 0.006 & & \\
\hline Red fibre number & Age & & & 30.06 & $<0.0001$ \\
\hline Mean red fibre diameter & Age & & & 27.27 & $<0.0001$ \\
\hline White CSA & Age & 8.86 & 0.005 & & \\
\hline White fibre number & Age & 9.97 & 0.003 & & \\
\hline Mean white fibre diameter & Age & & & 81.98 & $<0.0001$ \\
\hline White fibre nuclei & Age & & & 5.44 & 0.025 \\
\hline Red CSA & Length & ns & & & \\
\hline Red fibre number & Length & ns & & & \\
\hline Mean red fibre diameter & Length & ns & & & \\
\hline White CSA & Length & & & 13.52 & 0.0007 \\
\hline White fibre number & Length & ns & & & \\
\hline Mean white fibre diameter & Length & & & 17.53 & 0.0002 \\
\hline White fibre nuclei & Length & ns & & & \\
\hline
\end{tabular}

but there were no significant differences between early- and mid-season larvae (Table 2). In comparison, early-season larvae had a significantly smaller white muscle CSA than mid-season larvae $\left(F_{[1,37]}=13.52\right.$, $\mathrm{p}<$ 0.001; ANCOVA) (Tables 1 \& 2, Fig. 6a). This was due to the smaller mean fibre diameters of the early-season group $\left(F_{[1,37]}=17.52, \mathrm{p}<0.001 ;\right.$ ANCOVA $)$ (Tables 1 \& 2, Fig. 6c), and not to any significant differences in white fibre number (Table 2, Fig. 6b). Mean smooth probability densities of muscle fibre diameter at $23.7 \pm$ $0.7 \mathrm{~mm}$ L (mean $\pm \mathrm{SD}$ ) are shown for early- and midseason larvae (Fig. 7). In both groups, the distribution of fibre diameters was unimodal, with a peak between 3 and $5 \mu \mathrm{m}$ diameter (Fig. 7). Fibre diameter means \pm SD for the 50th, 95th and 99th percentiles in the midseason larvae were $10.4 \pm 0.6,29.6 \pm 1.4$ and $37.4 \pm$ $1.6 \mu \mathrm{m}$, respectively, compared to $9.5 \pm 0.5,25.7 \pm 1.6$ and $32.7 \pm 2.5 \mu \mathrm{m}$, respectively, in the early group ( $\mathrm{p}<$ 0.05 , Wilcoxon rank-sum test). In contrast, the 5 th and 10th percentiles were independent of larval group. Total white muscle nuclei increased with increasing length (Table 1), but did not show any significant differences between the 2 larval groups (Table 2, Fig. 6d).

The late group comprised 7 larvae, and therefore only limited statistical analysis was possible. However, it is worth noting that the group did produce significant regression lines for white muscle CSA $(y=0.04 x-0.60)$ and fibre number $(y=113 x-506.75)$ against length (Fig. 6a,b). Tukey multiple-comparison tests revealed no differences in the regression lines for CSA against length between the late- and mid-season group, but significant elevation of the slope (intercept $a$ ) in the late- compared to the early-season group $\left(q_{[3,41]}=5.67\right.$, $\mathrm{p}<0.005)$, Tukey multiple-comparison test (Fig. 6a). A similar pattern was observed for white fibre number against length $\left(q_{[3,41]}=3.83, \mathrm{p}<0.05\right.$, Tukey multiplecomparison test) (Fig. 6b).

\section{DISCUSSION}

The present study found batches of Clupea harengus larvae hatching over a 3 mo period during the spring in the Blackwater estuary. Each successive cohort experienced increasingly higher developmental temperatures. The larvae of early- and mid-season spawners had estimated growth rates of 0.23 and $0.34 \mathrm{~mm} \mathrm{~d}^{-1}$, respectively, that were not significantly different. Laboratory studies found that temperature variation had little effect on growth rates in herring larvae up to $75 \mathrm{~d}$ after hatching (Johnston et al. 1997, 1998). Henderson et al. (1984) sampled around 27000 herring larvae in the Blackwater estuary, over a period of $11 \mathrm{wk}$ during the spring of 1979. They reported a growth rate of $0.43 \mathrm{~mm} \mathrm{~d}^{-1}$ for larvae that were 28 to $50 \mathrm{~d}$ old. This age range is at the young end for our study, but such a growth rate has also been reported in spring-spawned Clyde herring up to $80 \mathrm{~d}$ old (Marshall et al. 1937). Although the lower estimated growth rates in the present study may be due to the reliance of age on otolith microincrement analysis, our values fall within the range of those reported in the literature for natural herring populations (mean growth rate of $0.28 \mathrm{~mm} \mathrm{~d}^{-1}$ for post yolk-sac Atlantic herring larvae) (McGurk 1984).

Mid-season larvae of approximately 50 to $70 \mathrm{~d}$ old were longer and had a greater muscle fibre CSA, more muscle fibres of greater average diameter, and more 

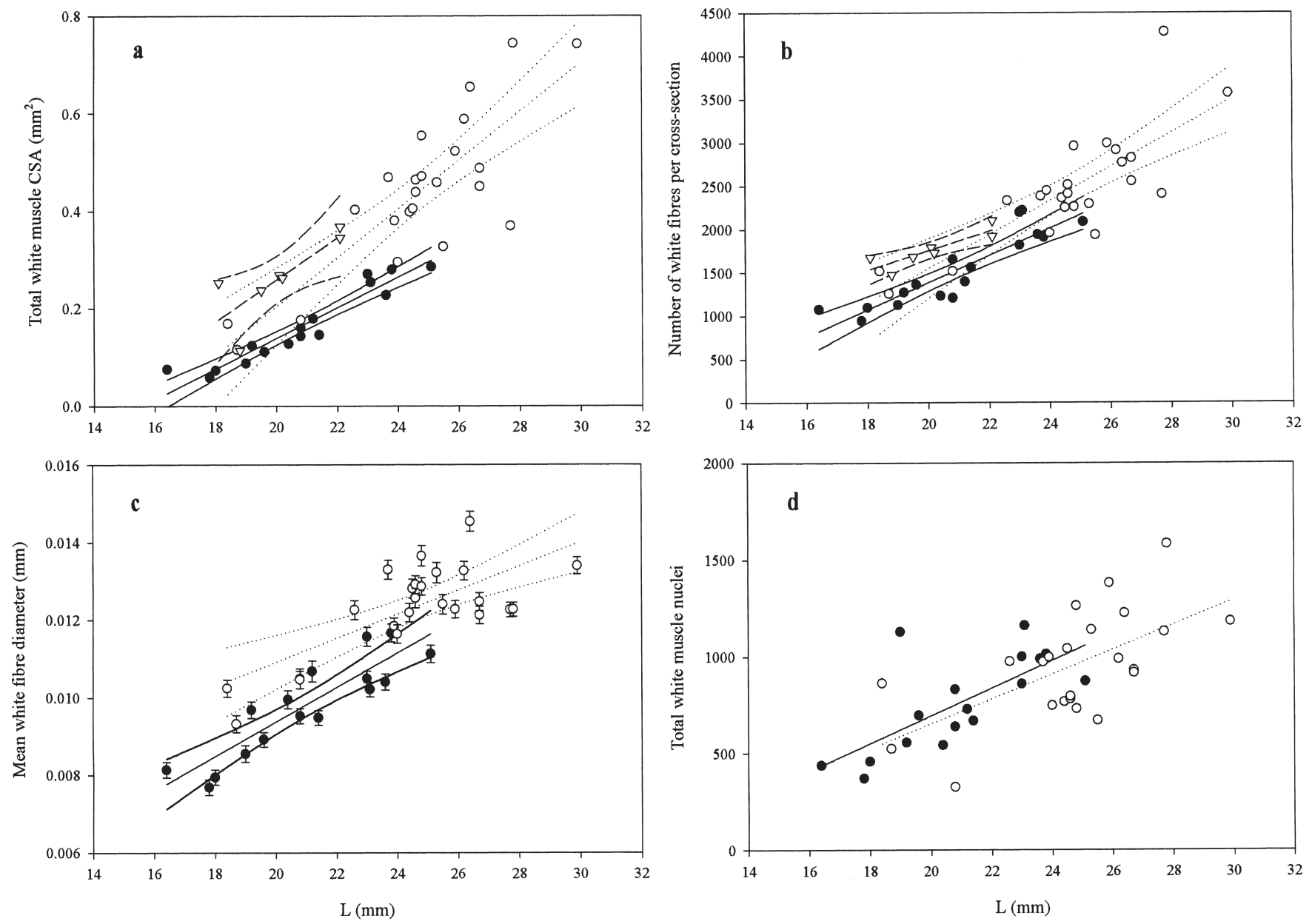

Fig. 6. Clupea harengus. Relationship between body length (L) and (a) total white muscle cross-sectional area (CSA), (b) total number of white muscle fibres, $(c)$ mean $( \pm \mathrm{SE})$ diameter of white fibres, and (d) total number of white muscle nuclei, per transverse-section of myotomal muscle in early $(\bullet$, continuous lines)-, mid ( 0 , dotted lines)- and late ( $\nabla$, dashed lines)-season larvae. $95 \%$ confidence intervals are shown in a, b and c

muscle nuclei than early-season larvae of the same age range. The mean hatch temperatures of the early- and mid-season larvae were 7 and $10^{\circ} \mathrm{C}$, respectively. For the red muscle, no differences in total CSA, fibre number or fibre diameter were found between early- and mid-season larvae after normalising for larval length. In contrast, at $24 \mathrm{~mm} \mathrm{~L}$, the total CSA of white muscle was about $50 \%$ greater in the offspring of mid- than early-season spawners. At this body length, the satellite cell phase was providing additional nuclei for new and existing fibres (Johnston et al. 1998) (Fig. 2). White fibre number was not significantly different between the 2 groups of the same length, whereas the mean white fibre diameter was around $31 \%$ greater in the mid- than in the early-season larvae. Thus, differences in the total CSA of white muscle was due to greater hypertrophic growth of fibres in the offspring of the mid-season spawners.
The present results parallel those of laboratory experiments by Johnston et al. (1998) in which herring eggs from the spring-spawning Clyde stock were incubated at 5 and $8^{\circ} \mathrm{C}$ until first feeding, when larval growth was continued at the same, but seasonally increasing, temperatures. Rearing temperature was found to alter the relative contributions of hypertrophy and muscle fibre recruitment to growth (Johnston et al. 1998). In addition, laboratory experiments have found that high temperatures lead to short, deeper-bodied larvae (Blaxter 1992, Vieira \& Johnston 1992). Similarly, in the present study, the lateseason larvae experienced the highest temperatures (mean hatching temperature of $15^{\circ} \mathrm{C}$ ), but were shorter than both of the other groups for a given age, and for a given length had values of white fibre CSA and number comparable to those of the stockier midseason larvae. 


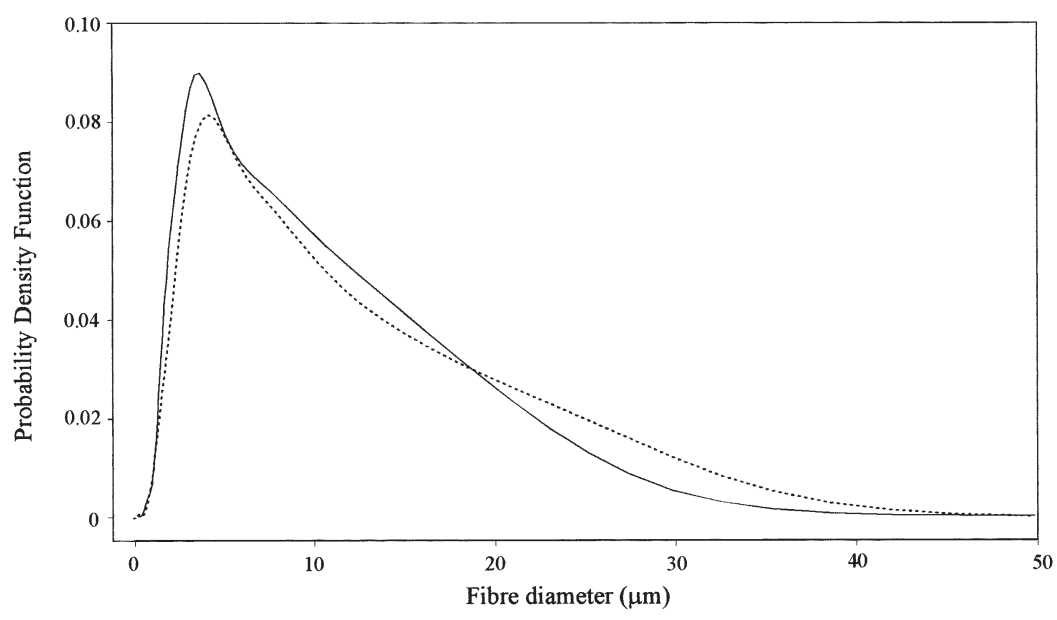

Fig. 7. Clupea harengus. Mean smooth probability density functions of white muscle fibre diameter in offspring of early-season (continuous line) $(\mathrm{n}=6)$ and mid-season (dotted line) $(\mathrm{n}=6)$ spawners

Fox et al. (1999a) found that the concentration of suitable prey of copepod nauplii, copepodites and adults in the Blackwater estuary appeared low compared with reported levels necessary for larval herring growth. At intermediate energy levels, turbulence has been predicted to enhance ingestion rates in large larvae experiencing low food concentrations (Fiksen et al. 1998, Fiksen \& Folkvord 1999). The tidally induced turbulence of the shallow Blackwater estuary is thought to significantly increase encounter rates between herring larvae and their prey (Fox et al. 1999a). Nevertheless, surveys of the spring plankton abundance in the Blackwater estuary in 1993, 1996 and 1997 found numbers of copepod nauplii to be less than $5 \mathrm{l}^{-1}$ in March,

Johnston et al. (1998) found that the fibre number: length ratios for larvae of the spring-spawning Clyde herring varied with rearing temperature, possibly reflecting the effect of embryonic temperature on the number of muscle satellite cells (Johnston 1993). In the present study, there was no evidence that the fibre number versus length relationship was different between the early- and mid-season Blackwater herring larvae. If temperature were the only variable to consider, it is possible that such differences might reflect developmental variations between populations. Studies on the effects of the relative timing of myogenesis in herring embryos have found distinct differences between Clyde and Blackwater stocks (Johnston et al. 2000b). Under natural conditions, developmental differences between the stocks may relate to the thermal tidal cycling of the Blackwater estuary. It has been suggested that the temperature cycling may be due to the extensive tidal flats acting as heating accelerators at that time of year (Talbot 1967).

Temperature, of course, does not affect larval growth in isolation, but interacts with numerous other factors, many of which concern feeding success. Unfortunately, there are few studies on the effects of different feeding regimes on muscle growth in fish larvae. However, Galloway et al. (1999) fed cod larvae with rotifers having either a high or low ratio of docosahexaenoic acid to eicosapentaenoic acid between 5 and $17 \mathrm{~d}$ post-hatch, after which an identical diet of enriched Artemia sp. nauplii was fed up to $31 \mathrm{~d}$ post-hatch. There was no evidence for any effect on larval length. However, the total CSA of white fibres increased at a significantly greater rate in larvae with the high rather than low ratio fatty acid diet (Galloway et al. 1999). increasing to $5-10 \mathrm{l}^{-1}$ by mid-May (Fox et al. 1999b). If this pattern had also occurred in 1998, then the earlyseason larvae would have had a lower food supply than the mid-season larvae around the critical time of first-feeding (Hjort 1914). Differences in food availability may have contributed to the greater white muscle CSA of the mid- compared to the early-season larvae of the same length. Galloway et al. (1999) found that the increased white muscle growth in cod larvae fed a superior diet was due solely to a greater contribution of hyperplasia. In contrast, the greater white muscle growth of the Blackwater mid-season herring larvae was associated with superior hypertrophic growth. Previous studies have found that exercise stimulates hypertrophic growth in fish (Greer-Walker 1971, Greer-Walker \& Pull 1973, Greer-Walker \& Emerson 1978, Johnston \& Moon 1980, Totland et al. 1987), possibly via the calcineurin/NF-ATc1 signalling pathway (Musarò et al. 1999, Semsarian et al. 1999). Hypertrophic muscle growth in the mid-season larvae may have been the result of higher feeding activity or an interaction between food availability and foraging activity.

The greater muscle mass of the mid-season Blackwater larvae may have important consequences in terms of survival and recruitment. Maximum swimming performance is limited by the power available from the muscle (Wakeling \& Johnston 1998, Wakeling et al. 1999). White muscle is required for faststarts employed during escape responses as well as prey-capture manoeuvres (Bone 1978, Domenici \& Blake 1997). Thus, the mid-season larvae may have had superior feeding performance and experienced less predatory mortality than the early-season larvae. 
It may be possible to use some aspects of muscle growth as indicators of larval quality in natural populations. There are numerous indices that use either morphometric, histological or biochemical measurements (Ferron \& Leggett 1994). The number and size of muscle fibres are functions of growing opportunity over periods of weeks or months. The percentage of activated satellite cells, however, may be used to give a more immediate measure of feeding opportunity over a period of a few days. The c-met receptor tyrosine kinase has been shown to be a molecular marker for muscle satellite-cells in the mouse (Cornelison \& Wold 1997) and various fish species (Johnston et al. 2000a). The division products of satellite cells committed to terminal differentiation express myogenic regulatory factors (MRFs) belonging to the MyoD gene family (Weintraub et al. 1991). The ratio of c-met to MRFexpressing satellite cells has been shown to be very sensitive to nutritional status in Atlantic herring, with the number of MRF-positive cells decreasing dramatically after 1 d starvation (Johnston \& Vieira unpubl. data). Thus, the examination of satellite-cell expression patterns using immunohistochemistry may be a useful addition to measures of larval condition.

Acknowledgements. This work was supported by a grant from the Natural Environment Research Council awarded under the Developmental Ecology of Marine Animals programme and partially by MAFF through MF0420 Physical and Biological Controls of Fish Stocks. We wish to thank Trinity House Lighthouse Service for permission to deploy temperature loggers in the Blackwater estuary.

\section{LITERATURE CITED}

Altringham JD, Johnston IA (1988) Activation of multiple innervated fast and slow myotomal muscle fibres of the teleost Myoxocephalus scorpius. J Exp Biol 140:313-324

Batty RS (1984) Development of swimming movements and musculature of larval herring (Clupea harengus). J Exp Biol 110:217-229

Blaxter JHS (1992) The effect of temperature on larval fishes. Neth J Zool 42:336-357

Bone Q (1978) Locomotor muscle. In: Hoar WS, Randall DJ (eds) Fish physiology, Vol VII. Academic Press, London, p 361-424

Bone Q, Kiceniuk J, Jones DR (1978) On the role of different fibre types in fish myotomes at intermediate swimming speeds. Fish Bull US 76:691-699

Bowman AW, Azzalini A (1997) Applied smoothing techniques for data analysis. The kernel approach with S-Plus illustrations. Oxford University Press, Oxford

Campana SE, Gagne JA, Munro J (1987) Otolith microstructure of larval herring (Clupea harengus): image or reality? Can J Fish Aquat Sci 44:1922-1929

Cornelison DDW, Wold BJ (1997) Single-cell analysis of regulatory gene expression on quiescent and activated mouse skeletal muscle satellite cells. Dev Biol 191:270-283

Crockford T, Johnston IA (1993) Developmental changes in the composition of myofibrillar proteins in the swimming muscles of Atlantic herring, Clupea harengus. Mar Biol $115: 15-22$

Cushing DH (1990) Plankton production and year-class strength in fish populations: an update of the match/mismatch hypothesis. Adv Mar Biol 26:249-293

de Silva C (1974) Development of the respiratory system in herring and plaice larvae. In: Blaxter JHS (ed) The early life history of fish. Springer-Verlag, Berlin, p 465-485

Domenici P, Blake RW (1997) The kinematics and performance of fish fast-start swimming. J Exp Biol 200: 1165-1178

Doyle MJ (1977) A morphological staging system for the larval development of the herring, Clupea harengus L. J Mar Biol Assoc UK 57:859-867

Ferron A, Leggett WC (1994) An appraisal of condition measures for marine fish larvae. Adv Mar Biol 30:217-303

Fiksen Ø, Folkford A (1999) Modelling growth and ingestion processes in herring Clupea harengus larvae. Mar Ecol Prog Ser 184:273-289

Fiksen Ø, Utne ACW, Aksnes DL, Eiane K, Helvik JV, Sundby S (1998) Modelling the influence of light, turbulence and development on foraging in larval cod and herring. Fish Oceanogr 7:354-363

Fox CJ (1996) Length changes in herring (Clupea harengus) larvae: effects of capture and storage in formaldehyde and alcohol. J Plankton Res 18:483-493

Fox CJ, Harrop R, Wimpenny A (1999a) Feeding ecology of herring (Clupea harengus) larvae in the turbid Blackwater Estuary. Mar Biol 134:353-365

Fox CJ, Milligan SP, Holmes AJ (1999b) Spring plankton surveys in the Blackwater Estuary: 1993-1997. Centre for Environment, Fisheries and Aquaculture Science, Lowestoft (Sci Ser Tech Rep No. 109)

Gallego A, Heath MR, McKenzie E, Cargill LH (1996) Environmentally induced short-term variability in the growth rates of larval herring. Mar Ecol Prog Ser 137:11-23

Galloway TF, Kjørsvik E, Kryvi H (1999) Muscle growth and development in Atlantic cod larvae (Gadus morhua L.) related to different somatic growth rates. J Exp Biol 202: 2111-2120

Geffen AJ (1983) The deposition of otolith rings in Atlantic salmon, Salmo salar L., embryos. J Fish Biol 23:467-474

Greer-Walker M (1971) Effect of starvation and exercise on the skeletal muscle fibres of the cod (Gadus morhua L.) and the coalfish (Gadus virens L.), respectively. J Cons Int Explor Mer 33:421-427

Greer-Walker M, Emerson L (1978) Sustained swimming speeds and the myotomal muscle function in the trout (Salmo gairdneri). J Fish Biol 13:475-481

Greer-Walker M, Pull GA (1973) Skeletal muscle function and sustained swimming speeds in the coalfish (Gadus virens L.). Comp Biochem Physiol A 44:495-502

Greer-Walker M, Bird AC, Pull GA (1972) The total number of white skeletal muscle fibres in cross-section as a character for stock identification in North Sea herring (Clupea harengus). J Cons Int Explor Mer 34:238-243

Heath MR, MacLachlan P (1987) Dispersion and mortality of yolk-sac herring (Clupea harengus L.) larvae from a spawning ground to the west of the Outer Hebrides. J Plankton Res 9:613-630

Henderson PA, Cartwright GH (1980) The dispersal of larval herring (Clupea harengus) in the Blackwater estuary, Essex, 1979. Central Electricity Research Laboratories, Leatherhead, Surrey

Henderson PA, Whitehouse JW, Cartwright GH (1984) The growth and mortality of larval herring, Clupea harengus 
L, in the River Blackwater estuary, 1979-1980. J Fish Biol 24:613-622

Hjort J (1914) Fluctuations in the great fisheries of northern Europe. Rapp P-V Réun Cons Int Explor Mer 20:1-228

Hovenkamp F, Witte JIJ (1991) Growth, otolith growth and RNA/DNA ratios of larval plaice Pleuronectes platessa in the North Sea 1987 to 1989. Mar Ecol Prog Ser 70:105-116

Johnston IA (1993) Temperature influences muscle differentiation and the relative timing of organogenesis in herring (Clupea harengus) larvae. Mar Biol 116:363-379

Johnston IA, Horne Z (1994) Immunocytochemical investigations of muscle differentiation in the Atlantic herring (Clupea harengus: Teleostei). J Mar Biol Assoc UK 74:79-91

Johnston IA, Moon TW (1980) Endurance training in fast and slow muscles. J Comp Biochem 135:147-156

Johnston IA, Davison W, Goldspink G (1977) Energy metabolism of carp swimming muscles. J Comp Physiol 114: 203-216

Johnston IA, Vieira VLA, Abercromby M (1995) Temperature and myogenesis in embryos of the Atlantic herring Clupea harengus. J Exp Biol 198:1389-1403

Johnston IA, Cole NJ, Vieira VLA, Davidson I (1997) Temperature and developmental plasticity of muscle phenotype in herring larvae. J Exp Biol 200:849-868

Johnston IA, Cole NJ, Abercromby M, Vieira VLA (1998) Embryonic temperature modulates muscle growth characteristics in larval and juvenile herring. J Exp Biol 201: 623-646

Johnston IA, Strugnell G, McCraken ML, Johnstone R (1999) Muscle growth and development in normal sex ratio and all-female diploid and triploid Atlantic salmon. J Exp Biol 202:1991-2016

Johnston IA, McLay HA, Abercromby M, Robins D (2000a) Phenotypic plasticity of early myogenesis and satellite cell numbers in Atlantic salmon spawning in upland and lowland tributaries of a river system. J Exp Biol 203: $2539-2552$

Johnston IA, Vieira VLA, Temple GK (2000b) Functional consequences and population differences in the developmental plasticity of muscle to temperature in Atlantic herring Clupea harengus. Mar Ecol Prog Ser (in press)

Koumans JTM, Akster HA, Booms GHR, Lemmens CJJ, Osse

Editorial responsibility: Roger Hughes (Contributing Editor), Bangor, Wales, UK
JWM (1991) Numbers of myosatellite cells in white axial muscle of growing fish: Cyprinus carpio L. (Teleostei). Am J Anat 192:418-424

Marshall SM, Nicholls PM, Orr AP (1937) On the growth and feeding of the larval and post-larval stages of the Clyde herring. J Mar Biol Assoc UK 22:245-267

McGurk MD (1984) Effects of delayed feeding and temperature on the age of irreversible starvation and on the rates of growth and mortality of Pacific herring larvae. Mar Biol 84:13-26

Musarò A, McCullagh KJA, Naya FJ, Olson EN, Rosenthal N (1999) IGF-1 induces skeletal myocyte hypertrophy through calcineurin association with GATA-2 and NFATc1. Nature 400:581-585

Rome LC, Funke RP, Alexander RMcN, Lutz G, Aldridge H, Scott F, Freadman M (1988) Why animals have different muscle fibre types. Nature 335:824-827

Semsarian C, Wu MJ, Ju YK, Marciniec T, Yeoh T, Allen DG, Harvey RP, Graham RM (1999) Skeletal muscle hypertrophy is mediated by a $\mathrm{Ca}^{2+}$-dependent calcineurin signalling pathway. Nature 400:576-580

Talbot JW (1967) The hydrography of the estuary of the River Blackwater. Fish Invest 25:1-92

Totland GK, Kryvi H, Jødestøl KA, Christiansen EN, Tangeras A, Slinde E (1987) Growth and composition of swimming muscle of adult Atlantic salmon (Salmo salar L.) during long-term sustained swimming. Aquaculture 66:299-313

Vieira VLA, Johnston IA (1992) Influence of temperature on muscle-fibre development in larvae of the herring Clupea harengus. Mar Biol 112:333-341

Wakeling JM, Johnston IA (1998) Muscle power output limits fast-start performance in fish. J Exp Biol 201:1505-1526

Wakeling JM, Kemp KM, Johnston IA (1999) The biomechanics of fast-starts during ontogeny in the common carp Cyprinus carpio. J Exp Biol 202:3057-3067

Weintraub H, Davis R, Tapscott SJ, Thayer M, Krause M, Benezra R, Blackwell TK, Turner D, Rupp R, Hollenberg S, Zhuang Y, Lassar A (1991) The MyoD gene family: nodal point during specification of the muscle cell lineage. Science 251:761-766

Zar JH (1996) Biostatistical analysis, 3rd edn. Prentice-Hall, Englewood Cliffs, NJ

Submitted: February 25, 2000; Accepted: April 26, 2000

Proofs received from author(s): September 29, 2000 